\title{
AS ROMANAS E O PODER NOS ANAIS DE TÁCITO
}

\section{Taís Pagoto Bélo* * Doutora em \\ Pedro Paulo Abreu Funari** História pela \\ Universidade \\ Estadual de \\ Campinas.}

RESUMO: Este artigo tem como objetivo o estudo de como a mulher da elite romana aparece na literatura latina. Tácito, em Anais, descreve, uma vez e outra, mulheres romanas associadas ao poder imperial central de forma pejorativa, como usurpadoras, quando associadas a questão do poder.

PALAVRAS-CHAVE: Romanas; poder; mulheres.

ROMAN WOMEN AND POWER IN TACITUS’ANNALS

ABSTRACT: The paper aims at studying how Roman elite women appear in Latin literature. Tacitus in the Annals describe time and again Roman women associated to central imperial power in a bad light, as usurpers, when associated to power issues.

KEYWORDS: Roman women; power; women.

\section{INTRODUÇÃO}

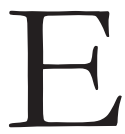

ste trabalho tem como intuito a realização de um estudo sobre as mulheres romanas, do final da República e Império, e como elas foram descritas por autores da Antiguidade, durante o século I d.C., como, em particular, Tácito (54/57 d.C. 117 d.C.), que quando as narrava as descrevia de forma pejorativa, acusando-as de todos os transtornos imperiais e culpando-as da má governança imperial. ${ }^{1}$ Essas mulheres, que sofreram com o limite de atuação de poderes, viveram em uma sociedade em que deveriam ser submissas a uma figura masculina, mesmo que isso, na prática, não se verificasse.

A marginalização da figura da mulher se propagou desde muito cedo, ao longo do tempo, devido à formação de estereótipos de gênero, os quais surgiram em distintos contextos culturais e históricos, estabelecendo padrões para o papel do homem e da mulher

\footnotetext{
${ }^{1}$ Este estudo é fruto da pesquisa realizada sob fomento do CNPq, PD Júnior, na Unicamp, sob supervisão de Pedro Paulo A. Funari.
} 
e sendo constituídos por meio educacional e familiar. Os padrões de gênero, dessa forma, são construções sociais que ocorrem em diferentes culturas e momentos históricos (Mead, 1969; Whitaker, 1995; Nolasco, 1993; Maia, 2005; Reis; Maia, 2009, p. 137). Eles são ligados à própria sociedade, que compartilha o mesmo pensamento, dentro de uma mesma cultura, e os reforça através da educação (Pereira, 2002, p. 52; Reis; Maia, 2009, p. 137).

Os estereótipos são um conjunto de crenças fixadas de acordo com o comportamento e as características sexuais adquiridos no processo de socialização junto à família, educação e outros meios que transmitem valores e convicções (Zenhas, 2007; Reis; Maia, 2009, p. 138). A sociedade reforça o processo sexista, estabelecendo concepções a serem percebidas como "naturais", em que a família, a religião, a educação e os meios de comunicação determinam ações, conceitos e estabelecem verdades absolutas, que reproduzem esses estereótipos (Souza, 2006; Reis; Maia, 2009, p. 138).

Isso acontece porque o ato de comunicação depende de um discurso comum ou ideológico sobre o que é esperado de membros de determinada identidade. Essas atividades são realizadas em base repetitiva e se tornam parte de rotinas. As ações normativas e os papéis são reforçados por meio do consentimento dos outros membros da sociedade, em geral para o indivíduo ser aceito no grupo social. A aprovação dos outros se torna um dos caminhos em que são construídas as atividades. As rotinas são estabelecidas por ações repetitivas, pelas quais o grupo internaliza vários aspectos de sua identidade. Mesmo as pequenas ações executadas, feitas sem pensar, são de alguma forma produtos de normas sociais, e dentro desses aspectos há elementos identificadores da identidade (Revell, 2016, p. 11).

Por esse viés, o desenvolvimento deste estudo objetiva apresentar o ponto de vista de Tácito diante das mulheres que ele próprio descreveu em sua obra Anais, na qual narra, a partir do livro I, os acontecimentos que ocorreram durante os anos 14 e 15, e que termina no livro XVI, no qual são descritos os eventos dos anos 65 ao 66, do primeiro século depois de Cristo. Sendo assim, as leis romanas para as mulheres, algumas atividades, como o patronato, e personagens femininas de Roma serão apresentadas aqui com o objetivo de exemplificar como a mulher romana era vista e a perspectiva de Tácito.

\section{As mulheres e a família romana}

Durante o período mais tardio da República, as mulheres raramente entravam no domínio do poder dos maridos (manus) ou recebiam posses quando eles morriam, uma vez que permaneciam sob o poder (potestas) de seus pais (paterfamilias). As filhas não podiam possuir propriedades ou assinar um contrato. Depois da morte do pai, ficavam independentes (sui iuris), mas, de qualquer forma, eram sujeitas a um tutor (Rawson, 2006, p. 332), ao menos em teoria.

Durante o Império, a família era a base da organização social romana, composta de pai, mãe, filhos, bem como escravos, animais e a própria propriedade, onde o pai exercia o domínio sobre todos e decidia seus destinos (Sampaio; Venturini, 2009, p. 2). O marido era casado com a esposa sob a forma de manus, que implicava um tipo de acordo de casamento 
em que a esposa ficava em poder (potestas) de seu marido. Ela tinha os mesmos direitos que os filhos do marido, quando este não fazia o testamento antes de sua morte. Entretanto, o poder do marido sobre ela era mais limitado do que sobre os filhos, não tendo o direito de vida ou morte sobre a esposa, ou mesmo direito de sua venda (como no coemptio, ${ }^{2}$ outro tipo de acordo de casamento, que estabelecia que, quando a esposa era vendida, todos os seus bens iam junto com ela, mesmo suas dívidas). Ela não podia ter, em teoria, uma propriedade e tudo o que recebia de presente ou de noivado, por exemplo, era investido por seu marido (Gardner, 1990, p. 11-12), com exceção de alguns direitos sobre seu dote, e o que ela recebia da vontade de seu marido dependia de sua generosidade (Gardner, 1990, p. 15).

O pater ${ }^{3}$ também poderia ser o avô ou até o bisavô, os quais possuíam a potestas de algumas pessoas (Gardner, 1990, p. 5), como da mulher e filhos. Diante da morte do pater, seus filhos e esposa tinham que ficar sob o controle de outro tutor (alieni iuris), ou independentes, sob a proteção da justiça do Estado. O filho adulto se tornava o paterfamilias e a mãe, materfamilias, casada sob manus (Gardner, 1990, p. 6-7). Era a família paterna que definia a identidade dos filhos e os vínculos de herança, como nome, culto e residência. Já a família da mãe, sem vinculações institucionais, estabelecia relações mais ternas com seus afilhados, netos e sobrinhos (Funari, 1993, p. 44). Os pais tinham o poder de decisão sobre a propriedade e o destino das mulheres e das crianças, ${ }^{4}$ que eram consideradas objetos de sua posse, como os animais e as plantações (Omena, 2007; Sampaio; Venturini, 2009, p. 2).

$\mathrm{O}$ acordo de casamento e a autoridade do pater estavam ligados à transmissão de propriedade, com o desejo de sempre manter a propriedade da familia o mais intacta possível. Para o requerimento do consentimento de casamento e do dote, é revelada toda a origem em relação ao controle romano da propriedade entre familiae (Gardner, 1990, p. 13-18). O dote era uma maneira que a família da esposa tinha de ajudar o marido nos gastos da casa e de manter o status social de cada um, ou seja, era um acordo entre famílias e não entre indivíduos. Quando a mulher entrava em um casamento por meio de manus, toda a sua propriedade era absorvida pelo marido ou pelo pater dele (Gardner, 1990, p. 97-98), se o marido estivesse ainda sob a potestas deste último. Dessa forma, com a morte do pai, o dote ia direto para o marido (Gardner, 1990, p. 108).

A declaração do dote poderia ser feita pela própria mulher, pelo seu pai ou pelo ascendente paternal, ou por uma terceira pessoa que estivesse em débito com a mulher. A promessa do dote poderia ser feita por outros que estivessem ligados à mulher ou ao seu pai, mas era o pater do futuro marido que questionava se as partes da mulher prometiam dar certa quantidade pelo dote. Entretanto, por mais que o dote fosse considerado uma

\footnotetext{
${ }^{2}$ Coemptio fiduciae causa, um modo de se vender uma mulher com o consentimento do tutor para um homem de escolha dela, o qual se tornava o tutor fiduciarius. Isso significava o fim da potestas, finalizando com o pater como tutor, tornando-se um tutor legitimus, que protegia sua família em relação aos direitos de sucessão sem testamento (Gardner, 1990, p. 17).

${ }^{3} \mathrm{O}$ poder do pater sob a familia tem origem primitiva na sociedade romana, de quando a proteção do grupo dependia de esforços do próprio grupo e não estava sob as regras da lei (Gardner, 1990, p. 6). ${ }^{4}$ No caso de impureza das filhas, por exemplo, o pater poderia condená-las à morte (Gardner, 1990, p. 7).
} 
propriedade sob a proteção do marido, seu propósito servia para a manutenção da esposa, sendo que, em um evento de dissolução do casamento, a família da esposa tinha todo o direito de reclamar de volta o dote, o que fez com que houvesse restrições para o uso do dote, de modo que quem reclamava pelo retorno desse dote era o pai da esposa, ainda quando estivesse vivo, mas somente poderia fazer isso com o consentimento da filha. Ulpiano (120 d.C. -180 d.C.), jurista romano, ressalta que o dote era patrimônio da filha; já Trifonino (século II d.C.), também jurista romano, menciona que o dote era parte da propriedade do marido, porém ele era da esposa (Gardner, 1990, p. 99-112).

A própria patria potestas é significante e uma marca das relações de poder do pai dentro da família romana, classificando a mulher como desigual ao homem, bem como as crianças. A ideologia por meio de cada identidade de gênero era legitimada com valores desiguais entre homens e mulheres, o que era aceito pelos dois grupos e internalizado mediante atividades cotidianas. Revell ressalta que é preciso aceitar que os múltiplos aspectos da identidade de um indivíduo vêm junto com outro indivíduo, permitindo salientar que uma mulher da elite romana, por exemplo, pudesse se apropriar de elementos da identidade masculina, criando níveis de tensão dentro da hierarquia social de Roma. O discurso da prática, que cria o senso de identidade, também era usado em uma revelação contínua e de renegociação do poder social para cada indivíduo (Revell, 2016, p. 15).

Contudo, é importante ter em mente quem, nesse momento, controla os diferentes papéis culturais de gênero e os relacionamentos, uma vez que o poder não é uma hierarquia estática, mas uma negociação dinâmica entre indivíduos. Dessa forma, homens e mulheres constroem diferentes significados sobre a ideologia de gênero dominadora. Assim, demonstrase neste estudo que as mulheres não apenas afrontaram a dominância masculina com suas estratégias, mas também foram agentes sociais, que tentaram criar suas próprias identidades e ideologias (Spencer-Wood, 1999).

\section{AS MULHERES IMPERIAIS}

As mulheres imperiais começaram a ganhar mais independência no final da República e início do Império, quando Lívia, mulher de Augusto, foi o grande exemplo. Lívia difundiu uma tendência de que as mulheres de família imperial poderiam desfrutar de considerável influência por meio de um representante. Porém, durante o período em que Tácito (54/57 d.C. - 117 d.C.) e Dião Cássio (155 d.C. - 235 d.C.) escreveram suas obras, algumas dessas poderosas mulheres da casa imperial já estavam mais bem consentidas no meio político, devido à sua atuação como matronas. Tem-se como exemplo as mulheres de Cláudio, Messalina, que foi executada (c. 47 e 48 d.C), e Agripina, mãe de Nero, admirada e temida (c. 48 e 54 d.C.), bem como a mulher de Augusto, Lívia (c. 14 e 15 d.C.). ${ }^{5}$ Entretanto, essas mulheres estavam sempre sujeitas a certo grau de limitação quanto à capacidade de serem

${ }^{5}$ Aldhouse-Green, 2006; Bélo, 2014, p. 9. 
independentes. A autoridade de agir era obtida pelo pai, marido ou guardião (tutor). Até o período de Augusto, as únicas exceções eram as virgens vestais (Gardner, 1990, p. 5).

Nos Anais, Tácito retrata a performance dessas mulheres imperiais, como é o caso de Lívia (14 e 15 d.C.), mulher de Augusto, descrita como o estereótipo da sogra má, apontando que ali havia um ciúme feminino, pois, segundo ele, Lívia sentia a amargura de sogra em relação a Agripina, a mais velha (Tac., An., I.33). Além disso, no início do livro XI (47-48 d.C.), Tácito deixa claro que a presença de mulheres na vida de Cláudio estava atrapalhando sua reputação, ao mencionar que Suílio o acusou de corromper as tropas por meio de suborno, bem como que ele era suspeito de adultério com Popeia, sugerindo ser um homem com vícios. Sendo assim, o autor relata o início dos jogos de Messalina, quando ela planeja a morte de Popeia, com a intenção de deixar parecer um suicídio (Tac., An., XI.2).

Tácito também afirma que, quando Messalina se casou com Cláudio (47 - 48 d.C.), seu poder seria igual ao de antes, adicionando a vantagem de uma mente quieta (Tac., $A n$., XI.26). Essa passagem revela o quanto o poder nas mãos dessas mulheres imperiais era enfatizado por Tácito. Ele defende, mais de uma vez, que os casamentos de imperadores com essas mulheres seriam um problema, como, por exemplo, quando ele relata a apatia de Cláudio e sua devoção à mulher, Messalina, que estaria no comando de vários assassinatos (Tac., An., XI.28).

Messalina foi acusada por Calpúrnia de se casar às escondidas com Sílio (Tac., An., XI.30), que tentou cometer suicídio devido à degradação de seu nome, mas o golpe de um tribuno foi dado a ela. Cláudio também foi acusado de adultério, contudo o peso do adultério feminino em relação ao masculino era muito maior. O Senado assistiu à condenação ao esquecimento (damnatio memoriae) de Messalina decretando que seu nome e suas estátuas deveriam ser removidos de todos os lugares, públicos e privados (Tac., An., XI.38). A conquista das mulheres, nessa época, de ter seus nomes lembrados, através de estátuas e placas, era recente e estabelecida através do patronato (Meyers, 2012). Dessa forma, a lembrança da pessoa era algo importante e poderia repercutir por gerações na família. Aqueles que foram alçados a altos cargos, mas que se mostraram indignos de suas honras, podiam ser apagados da memória do povo romano, a memória oficial, aquela a ser inscrita nos textos e nos artefatos materiais, por uma determinação do Senado. A essa prática se dava o nome de damnatio memoriae, "o apagar da memória", pelo desaparecimento de todas as referências à existência daquele ser em passagem pela face da Terra. Excluir qualquer referência ao morto era como deixar seu cadáver insepulto, uma das piores coisas que poderia ocorrer com os mortos, pois sua alma ficaria sem porto, sem direção (Gonçalves, 2014, p. 12-13).

Tácito descreve a imagem do governo de Nero como profundamente marcada pela influência feminina nos assuntos políticos. Com base no senso comum de sua sociedade, esse autor sugere que as más decisões de Nero somente foram possíveis em decorrência de conselhos dados por mulheres, tais como Agripina, sua mãe, Otávia, primeira esposa, de 53 a 62, e Popeia, segunda esposa, de 62 a 65. Tácito aponta a percepção de que seria impossível que um bom governo pudesse ser caracterizado pela presença feminina. A primeira fase do governo de Nero, por exemplo, que vai de 54 a 59, é descrita como uma administração de 
um bom homem, sem influências femininas. Todavia, do ano de 60 a 62, seu governo passa a ser descrito como passivo de manipulação feminina, razão pela qual, segundo a narrativa, decai. Já a terceira fase, do ano de 63 a 66, é o período de maior vício, em que o controle feminino sobre ele é mais destacado (Varella, 2006; Bélo, 2014, p. 10).

Conforme assinala Fischler (1994), as mulheres imperiais do período Júlio-Claudiano foram, em sua maioria, caracterizadas por Tácito como transgressivas e violadoras dos seus papéis na sociedade. O segundo século do período Júlio-Claudiano foi tido por Tácito como uma aberração na história de Roma, uma vez que os imperadores violaram os privilégios e ameaçaram a vida de senadores ou outras figuras de liderança (Fischler, 1994, p. 120).

Outro dado a se levar em conta diz respeito ao fato de que a tradição literária sempre teve um interesse particular para ser construída, o que sugere a necessidade de se comentar sobre essas mulheres que, aos olhos romanos, saíram dos padrões. Isso revela os abusos que em geral se acreditavam plausíveis e o que era censurável. A descrição dessas mulheres e seus comportamentos eram ressaltados para iluminar o caráter da "má" mulher imperial para o leitor e para mostrar o que esperavam de uma mulher de classe governante. Tais atitudes nos fazem indagar sobre o modo como as sociedades reagem diante de mulheres que possuem acesso à autoridade ou ao poder (Fischler, 1994, p. 121).

Essas mulheres imperiais, como Lívia, Julia e Agripina, muitas vezes tiveram que lidar com demandas de atividades que estavam fora dos limites dos afazeres da casa para preencher as responsabilidades familiares, momento em que elas entraram em contato com assuntos domésticos e públicos. Dessa forma, mulheres da elite romana teriam começado a conduzir os negócios da família e buscariam influenciar qualquer decisão tomada pelo dirigente da casa, o imperador. Sendo assim, a posição da mulher era fonte de tensão, revelando que nunca o poder do Estado poderia estar em suas mãos. Essas atividades levaram as mulheres a desenvolver o papel de patronas, ou de matres familias, que tinham por função tomar conta não apenas da própria família estendida, mas também de outras senatoriais, além de famílias de monarcas estrangeiros (Fischler, 1994, p. 122-123). O patronato ocorria quando um indivíduo provia uma doação vinda de suas riquezas em benefício da cidade ou de um pequeno grupo dentro dela (Meyers, 2012, p. 461). Com relação às mulheres, elas iniciariam essa atividade no final da República, supervisionando os negócios de família, possuindo escravos e protegendo libertos emancipados (Fischler, 1994, p. 124).

Um exemplo da tomada de posição feminina nesses assuntos de Estado aconteceu ao final do reinado do imperador Tibério, no qual sua mulher se tornou um reconhecido membro da hierarquia provincial. Seus deveres consistiam em acompanhar o marido em visitas oficiais e contribuir com a função de anfitriã. Entretanto, mesmo não tendo poder oficial, as mulheres de governadores podiam ser capazes de influenciar seus maridos em eventos políticos (Allason-Jones, 2005, p. 44).

No entanto, Julia foi julgada por sua libertinagem e confinada por seu pai, Augusto, na ilha de Pandatera. Tácito afirmou que ela desdenhava de seu marido, por não combinarem. Quando ele conseguiu o império, baniu-a e a deixou em desgraça, privada de toda a esperança depois do assassinato de Póstumo Agripa, permitindo que perecesse aos poucos até a morte. 
Tácito salienta que Tibério tinha razões para se vingar de Semprônio Graco, um homem de família nobre, que seduziu Júlia quando ela era casada com Marco Agripa. Quando ela foi entregue a Tibério, seu amante persistiu e a acusou de ser desobediente, fomentando o ódio de seu marido. Além disso, uma carta enviada por Júlia ao seu pai, injuriando Tibério, parece ter sido composta por Graco, que foi banido para Cercina, onde ficou exilado por 14 anos e depois foi executado (Tac., An., I.53).

Parece que Tácito mostra que essas mulheres estavam na posição de controlar os compromissos imperiais. Essa atividade era aceitável para uma mulher, mas não para uma mulher em contexto imperial. A preocupação com essas mulheres alcançava um alto patamar quando violavam o que era visto como funções primárias do imperador, infringindo seu dever para com o Estado e sugerindo que o poder não residia no próprio imperador. O papel fundamental do imperador era o de administrador da justiça. Isso provocou uma mudança na natureza de governar, o que colocou a mulher em uma posição próxima do centro do Estado e a deixou aberta a mudanças e influências nos negócios de Estado para ganho pessoal (Fischler, 1994, p. 125-127).

A atitude de Agripina, a mais velha (12 a.C. - 33 a.C.), durante uma empreitada dos romanos contra os germanos, mencionada por Tácito, demonstra bem esse olhar com o qual o autor, mesmo pelos bons atos dessas mulheres, as resguardou com suspeita. Quando o exército romano estava sem provisões, Agripina preveniu que uma ponte fosse destruída no Reno. Alguns, por covardia, não teriam ousado esse ato. Tácito destaca um espírito heroico de Agripina, que assumiu os deveres de um general e distribuiu roupas e medicamentos para os soldados; segundo Caio Plínio, da ponte, ela concedeu elogios e agradecimentos às legiões que voltavam. Toda essa atitude causaria uma profunda impressão em Tibério, que, segundo Tácito, pensou que todo esse zelo não poderia existir sem culpa e que não era contra os estrangeiros que ela estaria cortejando os soldados. Para Tácito, ela era uma mulher que ia até as comitivas, atendia a todas as medidas, aventurava-se ao suborno e demonstrava uma ambição para expor seu filho em uniforme comum de soldado, desejando que ele fosse chamado de César Calígula. Desse modo, Agripina conseguiu ter mais poder com os exércitos do que os próprios oficiais e generais. Uma mulher que dominou um motim em nome do soberano não era algo comum de ser observado, salientou Tácito (Tac., $A n$., I.69).

As atividades que envolviam as mulheres imperiais se tornaram padrões de categoria utilizados por esses autores para qualificar os imperadores, retratando, dessa forma, a qualidade e a natureza do governante "ruim". Fischler afirma que, para os romanos, os "bons" imperadores tinham mulheres e mães que eles podiam controlar e que nunca ultrapassariam limites. Contudo, por suas atividades tradicionais, elas estavam sujeitas à reinterpretação quando eram executadas por mulheres imperiais. Entretanto, essas mulheres faziam parte do império e eram vistas pelos homens da elite como ameaças a um "bom" governador. Por essa razão, escritores como Tácito e Dião Cássio utilizaram as "más” mulheres imperiais como sinônimo de Estado em desordem (Fischler, 1994, p. 127-128). 
A ameaça feminina é apresentada em outras situações, como nas leis que envolvem as heranças familiares. Hallett sugere que a lei, como a lex Oppida, ${ }^{6}$ designada para checar as extravagâncias das mulheres em relação à herança, ${ }^{7}$ foi aceita, pois as herdeiras de grandes riquezas eram tidas como ameaça à estrutura social patriarcal romana. ${ }^{8}$ No entendimento de Hallett (1984), essas herdeiras poderiam vir a tomar decisões em relação à família e, por fim, influenciariam nas interações familiares com a sociedade romana (Hallett, 1984; Gardner, 1990, p. 171).

${ }^{6}$ Uma das maiores lendas que influenciaram as leis romanas em relação à mulher foi o estupro de Lucrécia, que viveu durante o século VI a.C. e que consagrou o ideal feminino de castidade em honra das mulheres romanas determinadas a morrerem por isso. $\mathrm{O}$ estupro também é fator primordial na história de Virgínia, do século V a.C., que é apresentada como a mais indefesa das mulheres de alto status social, porém com caráter independente, como o de Lucrécia. Para não passar pela vergonha social da filha estuprada, seu pai decidiu tirar sua vida. Tito Lívio (I. 57-9), Cícero (Rep. II.25.46) e Juvenal (Sátiras X.193-5) utilizaram esses relatos para fazer alusões ao posicionamento da mulher na sociedade. Além do interesse político, esses comentários ficaram no inconsciente coletivo romano e perpetuaram a ideia da castidade feminina. Portanto, se uma mulher agisse de forma independente, os homens dessa sociedade eram criticados por não exercerem um controle sobre elas. Esse tipo de crítica foi expresso por Tito Lívio (XXXIV.1-8) a Catão, o mais velho, em 195, quando mulheres encenaram publicamente em Roma seu repúdio a Lex Oppida. Também o rapto das Sabinas era usado como alusão nesses casos (Rawson, 2006, p. 326-327). De acordo com Riess (2012), Tito Lívio faz elogio à castidade de Lucrécia (castitas), como ao seu orgulho feminino (decus muliebris). Para salvar a filha de ser violentada, Virgínio a mata com as próprias mãos (Tito Lívio III.44-58; Cícero, De re publica 2. 63). A castidade de Virgínia é elogiada por Lívio e Cícero em termos similares à de Lucrécia. Nos dois casos, a castidade e a pureza da mulher romana, como a inviolabilidade sexual, simbolizavam a invulnerabilidade da própria Roma. A honra do corpo feminino suportou o corpo político como um todo pelo senso de devoção (pietas), considerado essencial para a coesão política e social de Roma. A violência mitológica infligida a Lucrécia e Virgínia pode ser entendida como uma violência fundacional, pois o suicídio de Lucrécia desencadeou a queda dos Tarquínios e acelerou o despontar da República Romana. A morte de Virgínia acabou com os decênviros tirânicos e levou a um novo acordo entre patrícios e plebeus. Tais histórias criaram parâmetros de conduta feminina na imaginação de Roma. Outra mulher que exerceu grande influência foi Cornélia, casada com Tibério Semprônio, e que depois da morte do marido resolveu não se casar de novo (univira), ocupando-se da educação de seu filho. Dessa forma, foi homenageada com uma estátua de bronze. Assim, as mulheres ditas respeitáveis eram as amáveis esposas veneradas por seus maridos, as que sacrificavam suas vidas pela família, que eram social, urbana, educada e moralmente impecáveis (Riess, 2012, p. 492).

${ }^{7}$ A lex Voconia, de 169 a.C., proibia as mulheres de receberem herança, exceto quando fosse da vontade do falecido deixar algo para a filha, por exemplo (Gardner, 1990, p. 164-170).

${ }^{8} \mathrm{Na}$ prática, irmãos e irmãs eram considerados iguais perante o testamento. Entretanto, cada irmão, com a morte do pater, tornava-se pater da sua própria familia, com absoluto controle de sua propriedade e das finanças dos que estavam sob sua potestas (Gardner, 1990, p. 172), como era o caso da irmã, quando não casada, que precisava de um protetor para guardar seu dote. Se a filha fosse única, era perfeitamente legal que o pai indicasse um herdeiro de fora, mesmo deixando para ela um legado de até metade de sua propriedade (Gardner, 1990, p. 174). 
A retratação da própria imagem tinha muita conexão com o patronato, em especial a partir do século II d.C., quando aumentou a demanda de assuntos públicos para as mulheres imperiais e não imperiais. Desde quando iniciaram as atividades de patronato por essas mulheres que doavam fundos para prédios públicos, festas públicas e jogos, elas recebiam uma recompensa, como por exemplo um retrato de si mesmas em um local proeminente da cidade (Meyers, 2012, p. 453). Tais retratos poderiam ser em forma de estátuas ou, até mesmo, em moedas. Essas estátuas tendiam a celebrar assuntos de conexão familiar, mas aquelas de mulheres imperiais recebiam alguma característica física do imperador, visto que elas deviam sua posição ao membro da família que exercia a função imperial, o que demonstrava uma coesão da família imperial e o projeto de continuação dinástica, além de evocar temas como maternidade, felicidade e fertilidade. A atividade pública feminina contribuiu para a vida das suas cidades através de trabalhos de escritório, doações de dinheiro ou outros recursos, subsidiando o entretenimento público e a construção de prédios (Meyers, 2012, p. 460-461).

Os beneficiários também eram louvados por suas ações públicas de generosidade, através de inscrições honorárias, nas quais se omitia o motivo pelo qual o benefício era feito. A resposta a um determinado benefício, em geral, causava um impacto memorável, desde os menores, como uma placa com o nome, pelo fato de se ter doado azeite para uma casa de banhos, até os maiores, como a construção de um edifício na cidade com o nome do doador em tamanho gigantesco na fachada, de modo a ser lembrado por gerações. Isso também ajudava a moldar uma personalidade do doador (Meyers, 2012, p. 463).

Erigir estátuas de si mesmas e de outros membros da família em espaços públicos reforçava o lugar da família na história da cidade, difundindo suas ideias e crenças para os visitantes e residentes do local. As mulheres começaram a realizar esse tipo de atividade, pois talvez tivessem o mesmo desejo que os homens de receber glórias pela participação na vida pública. Além disso, pode ter sido uma forma de reação ao sistema de divisão, que formava uma tradição sobre a relação entre "público" e "privado" e que as permitiu participar dos negócios urbanos do mesmo modo que os homens. Tais eventos do período de Augusto corroboraram mudanças na cultura romana, permitindo que elas tivessem essa oportunidade, além de passarem a ser tidas como exemplo para outras mulheres. Essas ações foram imprescindíveis para a perpetuação da linhagem dinástica das famílias a que pertenciam (Meyers, 2012, p. 464-465).

A promoção dessas mulheres ao corpo imperial encorajou a atitude de ligá-las ao Estado, o que ajuda a explicar sua aparição na literatura. Nessa perspectiva, as mulheres e mães de imperadores que caíram em descréditos foram representadas como aquelas que tinham tudo para serem "boas", mas se tornaram "más". Essas representações recaem sobre a tensão gerada dentro da própria sociedade romana acerca do status da mulher e sobre o papel que ela exercia e se este era aceito pela sociedade. Tanto a elite quanto os imperadores se sentiam ambivalentes a respeito do lugar ideal para as mulheres imperiais, de modo que sua representação na literatura foi uma reação a essa tensão e ao produto contraditório da natureza do papel da mulher imperial (Fischler, 1994, p. 129-130). 
Pode-se rematar que o patronato abriu as portas para o uso do poder dessas mulheres e para uma atuação de gênero influente em relação a uma agência social criada por elas para extroverterem sua existência na sociedade romana. Deve-se perceber que elas não eram vítimas passivas da dominância masculina, mas encontraram meios e poder para moldarem suas próprias vidas.

\subsection{Agripina}

No início dos Anais, Tácito, ao mencionar Nero, salienta que este era o único enteado de Cláudio e que tudo estava centrado nele. Foi adotado como filho, como um amigo do império, um companheiro de poder nos tribunais e que ostentou todos os exércitos, não mais devido às intrigas secretas de sua mãe (Tac., An., I.3), Agripina, que o autor declara ter temperamento dominador, em virtude do seu sexo, bem como uma ambição extravagante (Tac., An., XII.57).

Agripina é uma das mais famosas mulheres imperiais, e que, segundo Anthony Barrett (1996) expressava seus atos da seguinte forma: depois da morte de Messalina (48 e 54 d.C.), Cláudio precisava de uma esposa em que pudesse confiar, porque carecia de uma aliada política para ajudá-lo a se manter distante das forças que ameaçavam derrubar seu principado. Além disso, ela deveria ser nobre de berço, com experiência materna, compartilhando seus descendentes com seus filhos, Britânico e Otávia, bem como ter pureza de caráter. Desse modo, notou que Agripina tinha todas as características que desejava e, assim, a escolheu com sagacidade. Cláudio também procurou em outras casas nobres e elegeu aquela que já se encontrava, por descendência, em duas casas imperiais (Barrett, 1996, p. 95-101). De acordo com Tácito, Palas elegeu Agripina com especial louvor para Cláudio, pois esta traria o neto de Germânico, que era digno de uma posição imperial, vindo de uma família nobre e descendente da gens Claudia (Tac., An., XII.2).

Agripina era da gens Julia, por parte de sua mãe, Agripina, e da gens Claudia, por parte de seu pai, Germânico. Dessa maneira, poderia exercer papel político importante ao tentar amalgamar uma fenda surgida pelo fato de Augusto e Lívia não terem tido filhos que sobreviveram. O casamento de Cláudio com uma mulher descendente de família imperial poderia cicatrizar feridas do passado e diminuir a ameaça entre o casal. Além disso, Agripina já tinha um neto de Germânico, descendente de Augusto, forte candidato à sucessão. Por mais que Cláudio tivesse um filho para sucedê-lo, poderia querer uma garantia de que seu regime sobrevivesse. Contudo, seu interesse em se atrelar à família da gens Julia era ditado pelo fato de, assim, adquirir o título de "César", que era um cognome adquirido pelos Otavianos, quando foi adotado por Júlio César e transmitido mais tarde a Tibério e de Germânico a Calígula. O casamento de Cláudio com Agripina era a garantia de uma parceria perfeita, desde que ela compartilhasse com ele a união da tradição de duas dinastias, gerando força e estabilidade (Barrett, 1996, p. 96-98).

Agripina teve paciência e habilidade, características que ela sempre manteve, e, mesmo após seu casamento, aliou forças e destreza para abrir caminho para seu filho, Nero, que era três anos mais velho do que o filho de Cláudio, Britânico. Agripina sabia da ameaça 
que seu filho corria devido à presença de Britânico, sucessor natural do pai, por isso não esperou que os fatos acontecessem para entrar em ação (Barrett, 1996, p. 98), fazendo com que Cláudio adotasse Nero como filho e convocando Sêneca para ser seu tutor (Barrett, 1996, p. 98 e 114). Para firmar o futuro de seu filho, nada mais acertado do que casar Nero com a filha de Cláudio, Otávia, e sua primeira esposa, Messalina. Em seus Anais, Tácito menciona que Agripina, antes mesmo de se casar com Cláudio, fazia várias visitas ao tio e já era possuidora do "poder de esposa", estando certa de que iria se casar com ele. Por esse motivo, ela começou a visar grandes oportunidades e deu início a certas alianças, como o casamento entre seu filho e Otávia, que já estava prometida a Lúcio Silano (Tac., An., XII.3).

A descrição do ano de 49, por Tácito, começa com o casamento de Agripina e Cláudio, de modo que os problemas dessa união acabam por aparecer nos capítulos posteriores, a partir do momento em que Agripina nomeia Sêneca como tutor de Nero: "quia Seneca fidus in Agrippinam... et infensus Claudio" (Tac., An., XII, 8, 2), "pois Sêneca confiava em Agripina e era contrário a Cláudio” (Funari; Garraffoni, 2016, p. 124).

Tácito insiste em ressaltar as impropriedades da sexualidade de Agripina, sendo uma delas o próprio casamento com Cláudio, que era seu tio, irmão mais velho de seu pai (Barrett, 1996, p. 100-101), ato que, segundo as leis de Roma, consistia em incesto. Tácito declara que tal amor era ilícito, que eles não deveriam ousar celebrar as núpcias como de costume e que não havia precedentes para a introdução de uma sobrinha à casa do tio. Tal ato era, definitivamente, um incesto, declarou Tácito (Tac., An., XI.5).

Vitélio, no discurso para o Senado em defesa dessa união, explicou que um casamento com a filha do irmão era novidade para eles, mas que isso era comum em outros lugares e que não havia lei que o proibisse. E continuou afirmando que casamentos entre primos antes eram desconhecidos, mas naquela época eram frequentes, na medida em que o costume se adaptava à conveniência, de modo que essa novidade iria ocupar, no futuro, lugar entre os usos reconhecidos (Tac., An., XII.6). Sendo assim, os senadores aprovaram o casamento da filha de Germânico e a união passou a ser vista como apaziguadora de futuros conflitos para sucessão. Para Tácito, isso representou uma profunda degeneração moral, como no casamento de Otávia com Nero, que, segundo ele, foi a causa de todas as calamidades que sobrevieram (Barrett, 1996, p. 101-102), pois Nero foi adotado por Cláudio e passou a ser como um irmão para sua filha.

Para Tácito, o casamento de Cláudio significou a posse efetiva de Agripina no poder, sendo que nos relatos seguintes, do ano de 50 a 54 d.C., esse assunto é dominante, uma vez que o autor descreve a atividade da esposa em benefício de seu filho Nero e seu privilégio em receber o título de Augusta (Tac., An., XII, 25-26; XII, 41-43), além do casamento, em 53 d.C., de seu filho com Otávia e, em 54 d.C., do assassinato de Cláudio, por Agripina, para garantir o trono a Nero (Tac., An., XII, 64-69). Dessa forma, para Tácito, quem governava era Agripina e a ênfase dada "às relações pessoais e familiares e o efeito deletério do domínio de quem deveria ser subalterno" (uma mulher, Agripina) "fica evidente como motor da História" (Funari; Garraffoni, 2016, p. 125). Ao mencionar a exibição da luta de gladiadores, Tácito questiona como um príncipe, com seus meros dezessete anos, poderia lutar e evitar tal 
perigo, referindo-se a Agripina, bem como questiona como os romanos poderiam recorrer a alguém que era dominado por uma mulher (Tac., An., XIII.6). Um dos poucos momentos em que Tácito declara que a influência de Agripina sobre seu filho estava enfraquecendo é quando Nero se apaixona por uma mulher livre, Acte (Tac., An., XIII.12).

Como assinala Barrett (1996), Dião Cássio declarou que Agripina tinha Cláudio sob seu controle e que, para Tácito, esse casamento representava uma transformação no desenvolvimento do Estado de Roma, pois as relações estavam agora no controle de uma mulher, mas não uma mulher como Messalina, que se valeu do poder apenas para excessos, tendo em vista que o desejo de Agripina não era por paixão, e sim por poder. Tácito a concebia como uma pessoa austera, livre de conduta promíscua, senão para contribuir para seu poder. Mesmo sua ganância é vista pelo autor como um dispositivo para reforçar seu domínio. Dião Cássio menciona que, depois do casamento, Agripina passou a controlar completamente o marido com uma mistura de intimidação e suborno. Sua tática era arranjar um homem livre para persuadir Cláudio a seguir seus conselhos. Além disso, Dião Cássio expressa a passividade de Cláudio, que estava certo de que Agripina traria ao casamento um senso político aguçado (Barrett, 1996, p. 102-103).

Em 49, Agripina estava casada com o imperador de Roma e tinha noivado seu filho com a filha do seu marido. Seu sucesso ainda foi simbolizado pelo recebimento do título de Augusta em 50 d.C. Ela foi a primeira esposa de imperador vivo a receber esse título. Lívia, por exemplo, também o recebeu, mas já era viúva (Barrett, 1996, p. 108).

Agripina envenenou Cláudio para colocar Nero no poder (Tac., An., XII.66). Segundo Tácito, Palas sugeriu que Cláudio tinha arruinado a si mesmo, por meio de um casamento incestuoso e pela adoção fatal de um filho (Tac., An., XIII.2).

Um pouco antes da morte de Agripina, Tácito descreve o quase incesto entre ela e seu filho Nero (Tac., An., XIV.2). O autor menciona que, pela ânsia de manter a influência sobre o filho, que estava seduzido por Acte, ela se apresentou vestida de forma atraente para ele, tendo-se lhe ofertado. Depois desse episódio, Nero decidiu destruir sua mãe (Tac., An., XIV.3-4). Nos últimos anos da vida de Agripina, em 59 d.C. (Tac., An., XVI), aumentava cada vez mais a tensão entre ela e seu filho, que acaba por planejar seu assassinato. A narrativa de Tácito mostra sinais de que o imperador estava perdendo seu autocontrole e se deixava levar pelas paixões como se fosse uma mulher. "O tom condenatório à falta de moderação continua no relato dos anos seguintes", "sem freios, Nero cedia cada vez mais aos desejos e matava Sila, Rubélio, Otávia, Palas e Dariforo”, seguindo essa mesma tendência até o fim do seu governo e de sua vida (Funari; Garraffoni, 2016, p. 125-126). Além disso, antes da morte de Agripina, Tácito declara que, de todas as coisas humanas, a mais precária e transitória é a reputação pelo poder, que não tem um suporte forte em si mesmo (Tac., An., XIII.19). Com a morte de Agripina, Nero atribui à sua mãe todas as abominações ocorridas, procurando mostrar que foi a boa fortuna da república que a destruiu (Tac., An., XIV.11).

Quanto à última esposa de Nero, Popeia, Tácito narra a ação pesada e misógina de Nero e diz que sua morte fora decorrente de um ataque casual de raiva em relação ao seu marido. Ato utilizado como desculpa para a contrapartida do chute que Nero tinha lhe dado enquanto estava grávida (Tac., An., XVI.6). 
Tácito deu grande ênfase à trama familiar e psicológica das personagens, colocando em suas mãos os destinos administrativos. Sua abordagem, que parece muito com a de Salústio, expõe uma visão da degradação causada pela corrupção resultante do exercício do poder. Desse modo, domina em sua narrativa a concepção de que, se as pessoas cedem ao prazer, isso as arruína (Funari; Garraffoni, 2016, p. 126).

\section{Conclusão}

As imagens dessas figuras femininas nas narrativas antigas expõem muito mais sobre as atitudes romanas do que sobre como as mulheres viviam. Esse contexto possibilita compreender as relações de gênero e suas maneiras perante o poder, além de sugerir como as posições masculinas da elite, diante das relações de gênero e poder, influenciaram a representação feminina nos textos literários antigos, em geral escritos por homens de posses e comprometidos com o poder. Parece que a relação entre mulher e poder, ou, mais exatamente, das mulheres com o poder, era vista com desconfiança em grande parte dos círculos da elite. Nesse sentido, as mulheres que se distinguiam por terem acesso ao poder parecem ter sido vistas como aquelas que falharam em se conformar e aceitar a construção social dada a elas naquela sociedade, sendo representadas como mulheres problemáticas, causadoras de grandes tensões. Essa visão era produzida por autores antigos, ligados à elite governante da época, a qual se sentia ameaçada por essas mulheres. Não é de se surpreender que, nessas produções, as mulheres imperiais fossem retratadas, muitas vezes, como submissas, devido à importância simbólica de seus papéis na sociedade (Fischler, 1994, p. 115-116).

Não se pode deixar de considerar o papel oposto manifestado nessas mulheres nos textos antigos, o que sugere que a figura da mulher "má" também era uma construção cultural comum, como o era a da matrona ideal. A análise da posição dessas mulheres na sociedade romana serve para compreender a natureza de gênero ali existente, além da relação entre gênero e poder, sem deixar de envolver esse aspecto na estrutura sociopolítica daquela sociedade. No entanto, deve-se compreender que todas as sociedades constroem imagens de grupos nelas existentes em parte de acordo com valores e interesses do grupo dominante (Fischler, 1994, p. 116-120). Há muitas evidências arqueológicas em diferente sentido, como inscrições que retratam as mulheres de maneira positiva, ativa e em relações menos desiguais ou até mesmo dominantes (Funari, 1995), mas para recuperar essa agência feminina na literatura antiga convém, em geral, uma leitura a contrapelo.

As caracterizações das mulheres romanas devem ser colocadas em um contexto de conflito entre papéis aprovados para mulheres e aqueles que as colocam em uma posição de poderosas ameaçadoras. Nem todas as mulheres seriam dessa forma, contudo, de acordo com a natureza da monarquia, todas elas eram vistas como tendo potencial para se desenvolver nesse sentido (Fischler, 1994, p. 127). 


\section{Agradecimentos}

Agradecemos a Renata Senna Garraffoni, Richard Hingley e Renato Pinto. Mencionamos o apoio institucional do Departamento de História da Unicamp e do CNPq.

\section{REFERÊNCIAS}

ALDHOUSE-GREEN, Miranda. Boudica Britannia. London: Pearson Longman, 2006.

ALLASON-JONES, Lindsay. Women in Roman Britain. York: Council for British Archaeology, 2005.

ALDHOUSE-GREEN, Miranda. Women in Roman Britain. In: JAMES, L. S.; DILLON, S. (Ed.). A Companion to Women in the Ancient World. Oxford: Blackwell Publishing, 2012. p. 273-287.

BARRETT, Anthony A. Agrippina: sex, power, andpolitics in the Early Empire. Yale; London: Yale University Press, New Haven, 1996.

BELO, Tais P. Boudica e as facetas femininas ao longo do tempo: nacionalismo, feminismo, memória e poder. 2014. Tese (Doutorado em História Cultural) - Instituto de Filosofia e Ciências Humanas da Universidade Estadual de Campinas, Departamento de História, Campinas, 2014.

CASSIO DIO. Roman History. Tradução de E. Cary. London: W. Heinemann, 1914-1927.

CÍCERO, Marco Túlio. Da Republica. Tradução de Cisneiros. Ed. bilingue: latim-espanhol. São Paulo: Abril, 1973. v. II, 33.

FISCHLER, Susan. Social Stereotypes and Historical Analysis: the case of the imperial women at Rome. In: ARCHER, L.; FISCHLER, S.; WYKE, M. (Ed.). Women in Ancient Societies. New York: Routledge, 1994. p. 115-133.

FOUCAULT, Michel. The history of sexuality. London: Allen Lane, 1979. v. 1.

FUNARI, P. P. A. Romanas por elas mesmas. Cadernos Pagu, Campinas, v. 5, p. 179-200, 1995. FUNARI, Pedro P. A.; GARRAFFONI, Renata S. Historiografia: Salústio, Tito Livio e Tácito. Campinas: Editora Unicamp, 2016.

GARDNER, Jane F. Women in Roman law and society. London: Routledge, 1990.

HALLETT, Judith P. Fathers and daughters in Roman society. Princeton, 1984.

HINGLEY, R.; UNWIN, C. Boudica: Iron Age warrior queen. London: Hambledon Continuum, 2005.

JOHNSON, M. Boudicca. London: Bristol Classical Press, 2012.

JUVENAL. Sátiras. Traducción, estudio introductorio y notas de Bartolomé Segura Ramos. Madrid: Consejo Superior de Investigaciones Científicas, 1996. Disponível em: <https:// docs.google.com/file/d/0B9QFYOHNVhEIbW1zTWR2TVNGNE0/edit>. Acesso em: 13 jul. 2017. 
MAIA, Ana C. B. Identidade e papéis sexuais: uma discussão sobre gênero na escola. In: MAIA, A. C. B.; MAIA, A. F. (Org.). Sexualidade e Infância. Cadernos Cecemca, n. 1. Bauru: Faculdade de Ciências: Cecemca; Brasília: MEC/SEF, 2005. p. 66-82.

MEAD, Margaret. Sexo e temperamento. São Paulo: Perspectiva, 1969.

MEYERS, Rachel. Female portraiture and female patronage in the high imperial period. In: JAMES, S. L.; DILLON, S. (Ed.). A Companion to Women in the Ancient World. Malden; Oxford; Chichester: Blackwell Publishing, 2012. p. 453-466.

NOLASCO, Socrates. O mito da masculinidade. Rio de Janeiro: Rocco, 1993.

OMENA, Luciane M. Os ofícios: meios de sobrevivência dos setores subalternos da sociedade romana. Fenix: Revista de História e Estudos Culturais, São Paulo, ano IV, v. 4, n. 1, p. 1-13, 2007. ISSN: 1807-6971. Disponível em: < http:/ / www.revistafenix.pro.br/PDF10/ DOSSIE3.Luciane.Munhoz.de.Omena.pdf>. Acesso em: 7 nov. 2015.

PEREIRA, Marcos E. Psicologia social dos estereótipos. São Paulo: EPU, 2002.

PINTO, Renato. Duas rainhas, um príncipe e um eunuco: gênero, sexualidade e as ideologias do masculino e do feminino nos estudos sobre a Bretanha Romana. 2011. Tese (Doutorado em História Cultural) - Instituto de Filosofia e Ciências Humanas da Universidade Estadual de Campinas, Departamento de História, Campinas, 2011.

RAWSON, Beryl. Finding roman women. In: ROSENSTEIN, N.; MARX, R. M. (Ed.). A Companion to the Roman Republic. Oxford: Blackwell Publiching, 2006. p. 324-341.

REIS, Kellen C. F; MAIA, Ana C. B. Estereótipos sexuais e a educação sexista no discurso de mães. In: VALLE, T. G. M. (Org.). Aprendizagem e desenvolvimento humano: avaliações e intervenções [online]. São Paulo: Cultura Acadêmica, 2009. p. 137-154. ISBN: 978-85-98605-99-9. Disponível em: SciELO Books <http://books.scielo.org>.

REVELL, Louise. Ways of being Roman: discourses of identity in the Roman West. Oxford; Philadelphia: Oxbow Books, 2016.

RIESS, Werner. Rari exempli femina: female virtues on Rome. In: JAMES, S. L.; DILLON, S. (Org.). A Companion to Women in the Ancient World. Chichester: Wiley-Blackwell, 2012. p. 491-501.

SAMPAIO, Ângela O.; VENTURINI, Renata L. B. Uma breve reflexão sobre a família na Roma Antiga. VI Jornada de Estudos Antigos e Medievais - Trabalhos Completos, 2009. ISBN: 97885-99726-09-9. Disponível em: <http://www.ppe.uem.br/jeam/anais/2007/trabalhos/030. pdf $>$. Acesso em: 7 nov. 2015.

SOUZA, Fabiana C. Meninos e meninas na escola: um encontro possível? Porto Alegre: Zouk, 2006.

SPENCER-WOOD, Suzanne. Gendering power. In: SWEELY, T. (Ed.). Manifesting power: gender and the interpretation of power in Archaeology. London; New York: Routledge, 1999. p. 175-183. 
TACITUS, Publius C. The Annals and The Histories. Tradução de A. J. Church e W. J. Brodribb. Great Britain: Penguin Classics, 1952.

TITO LIVIO. História de Roma: ab urbe condita. Introdução, tradução e notas de Paulo Farmhouse Alberto. Lisboa: Inquérito, 1999.

VARELLA. Flávia. F. A proximidade feminina e a imagem Imperial: Nero, Tácito \& os Anais. Revista electronica: Cadernos de História, Ano I, n. 1, p. 1-12, 2006. Disponível em: <www.ichs. ufop.br/cadernosdehistoria>. ISSN 1980-0339.

WHITAKER, Dulce C. A. Menino - Menina: sexo ou gênero? In: SERBINO, R. V.; GRANDE, M. A. R. L. (Org.). A escola e seus alunos: o problema da diversidade cultural. São Paulo: Unesp, 1995. p. 31-52.

ZENHAS, Armanda. 2007. Estereótipos de gênero. In: Educare.pt, 14/03/2007. Disponível em: <https://www.educare.pt/opiniao/artigo/ver/?id=11982\&langid=1>. Acesso em: 27 abr. 2017. 